\title{
ENKEPHALIN REDUCES CALCIUM ACTION POTENTIALS IN ROHON-BEARD NEURONS IN VIVO ${ }^{1}$
}

\author{
JOHN L. BIXBY ${ }^{2}$ AND NICHOLAS C. SPITZER \\ Department of Biology, B-022, University of California, San Diego, La Jolla, California 920.93
}

Received October 1, 1982; Revised November 29, 1982; Accepted December 1, 1982

\begin{abstract}
Rohon-Beard neurons of the Xenopus spinal cord develop somatic $\mathrm{Ca}^{++}$-dependent action potentials at early embryonic stages. Because many $\mathrm{Ca}^{++}$-dependent events are blocked or reduced by enkephalin in other neuronal systems, we tested the effect of met-enkephalin on the $\mathrm{Ca}^{++}$spikes of Rohon-Beard cells. Our results indicate that met-enkephalin, which has no effect on the resting membrane potential or conductance in these cells, reversibly and specifically shortens their $\mathrm{Ca}^{++}$ action potentials, probably by decreasing the $\mathrm{Ca}^{++}$conductance. Enkephalin has a similar effect on Xenopus dorsal root ganglion cells in vivo. Examination of Rohon-Beard cells at various stages of development shows that enkephalin shortens $\mathrm{Ca}^{++}$spikes from the earliest times that the spikes appear ( $\sim 21 \mathrm{hr}$ after fertilization) to the latest times they are detectable ( 7 to 9 days). This very early response suggests either that enkephalin binds directly to the $\mathrm{Ca}^{++}$channels or that an "enkephalin receptor" is among the earliest neuronal phenotypes to appear in these cells.
\end{abstract}

Since their discovery, the opiate peptides have been implicated in an increasing variety of physiological roles. These various effects seem to be mediated through a similar array of physiological mechanisms, of which the most prominent is a reduction or block of events dependent on a voltage-sensitive $\mathrm{Ca}^{++}$influx. Such an action has been demonstrated in regions of both the central and peripheral nervous systems (Jessell and Iversen, 1977; MacDonald and Nelson, 1978; Konishi et al., 1979; Mudge et al., 1979; Lightman et al., 1982). These actions are generally interpreted as indicating a role of opiates, particularly enkephalin, in regulating transmitter release.

Calcium-dependent action potentials are a feature of scveral populations of developing excitable cells (Kano, 1975; Baccaglini and Spitzer, 1977; Baccaglini, 1978; Strichartz et al., 1980). In addition, mature neurons in some cases possess a Ca ${ }^{++}$component in largely $\mathrm{Na}^{+}$-dependent spikes (Koketsu and Nishi, 1969; Akaike et al., 1978; Yoshida et al., 1978). Mudge and co-workers (Mudge et al., 1979; Fischbach et al., 1981) found that the $\mathrm{Ca}^{++}$ component of spikes in cultured chick dorsal root ganglion cells is reduced by met-enkephalin applied to the

\footnotetext{
${ }^{1}$ We thank Darwin Berg for suggesting the conductance measurements, D. Berg and Bill Harris for helpful criticism of the manuscript, and Rosario de Baca for technical assistance. This research was supported by grants from the National Institutes of Health and the Office of Naval Research to N. C. S.

${ }^{2}$ To whom correspondence should be addressed, at the Department of Physiology, University of California, San Francisco, San Francisco, CA 94143.
}

soma, and they suggested that enkephalin may regulate the in vivo release of substance $\mathrm{P}$ by a similar action on $\mathrm{Ca}^{++}$channels at the terminal. However, in developing cells having action potentials wholly or predominantly dependent on $\mathrm{Ca}^{++}$, effects of enkephalin on voltagesensitive $\mathrm{Ca}^{++}$channels could be significant without regard to the control of transmitter release.

The Rohon-Beard neurons of the Xenopus tadpole pinal cord develop long duration $\mathrm{Ca}^{++}$action potentials very early during development (at the stage of neural tube closure), which later are transformed to brief, predominantly $\mathrm{Na}^{+}$-dependent events (Baccaglini and Spitzer, 1977). Because these neurons are accessible to study in vivo prior to their developing electrical or chemical excitability, and they go through a stage of $\mathrm{Ca}^{++}$. dependent impulses, we examined the effect of enkephalin on the Rohon-Beard cell action potentials. We found that met-enkephalin reduces or blocks the $\mathrm{Ca}^{++}$component of Rohon-Beard neuron action potentials, without affecting the resting membrane voltage or conductance. Furthermore, this effect is present from the earliest times that the $\mathrm{Ca}^{++}$channels are physiologically detectable and remains at least until the time of onset of cell death in the population.

\section{Materials and Methods}

Xenopus laevis embryos were obtained by conventional breeding procedures and staged according to the method of Nieuwkoop and Faber (1956). Preparations were dissected and mounted in chambers as described previously (Baccaglini and Spitzer, 1977; Bixby and 

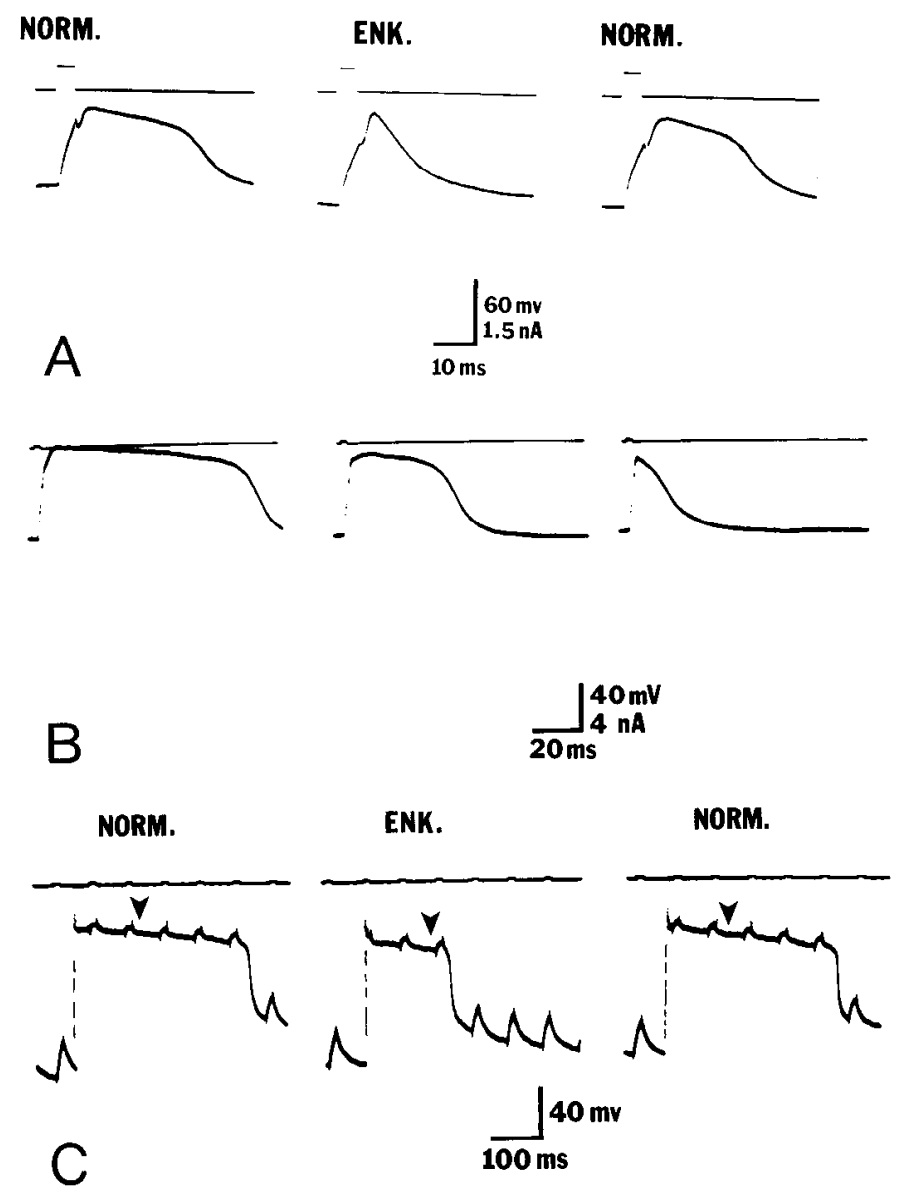

TEA

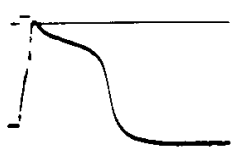

$D$

NORMAL

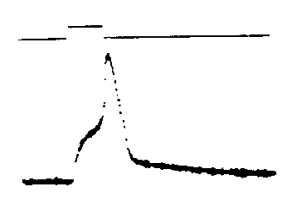

ENK./TEA TEA

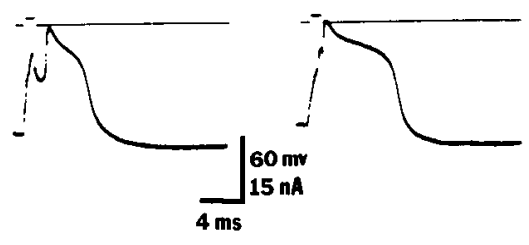

ENKEPHALIN

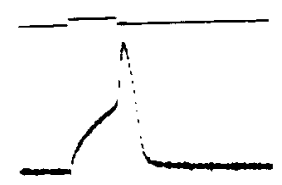

$E$

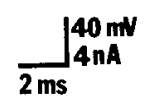

Figure 1. Puffer application of enkephalin shortens the $\mathrm{Ca}^{++}$ component of Rohon-Beard cell action potentials. Voltage records, lower traces; injected currents, upper traces. $A, 20 \mu \mathrm{M}$ enkephalin shortens the $\mathrm{Ca}^{++}$plateau of the $\mathrm{Na}^{++} / \mathrm{Ca}^{++}$action potential at stage 26 . The response returns when the puffer is turned off. $B, 10 \mu \mathrm{M}$ enkephalin reduces the amplitude and duration of the $\mathrm{Ca}^{++}$action potential at stage 22/23. Center trace, immediately following onset of application; right trace, after several seconds of application. $C, 20 \mu \mathrm{M}$ enkephalin decreases membrane conductance during the $\mathrm{Ca}^{++}$action poten-
Spitzer, 1982). Rohon-Beard neurons and dorsal root ganglion neurons were visualized with Nomarski interference contrast optics at $\times 500$ magnification.

Cells were impaled with glass microelectrodes filled with $3 \mathrm{M}$ potassium acetate, having resistances of 100 to 160 megohms. Currents and voltages were measured with a cathode follower amplificr having current injection capability and were displayed on an oscilloscope. Action potentials were elicited with short ( 1 to $2 \mathrm{msec}$ ) depolarizing current pulses of 0.5 to $3 \times 10^{-9} \mathrm{~A}$. Data were accepted only from cells having resting potentials (rps) more negative than $-40 \mathrm{mV}$, and most cells had rps between -50 and $-90 \mathrm{mV}$. Cells with small rps were often held at -60 to $-70 \mathrm{mV}$ with steady hyperpolarizing current.

We perfused the preparations continuously with amphibian saline, containing (in $\mathrm{mM}$ ): $\mathrm{Na}^{+}, 125 ; \mathrm{Cl}^{-}, 148$; $\mathrm{Ca}^{++}, 10 ; \mathrm{K}^{+}, 3$; HEPES buffer, 5 (pH 7.4). For animals younger than stage $30,10 \mathbf{m M ~} \mathbf{M g C l}_{2}$ was added to this saline to reduce muscle contraction. For older animals (stages 46 to 49 ), $20 \mathrm{~mm}$ tetraethylammonium chloride $\left(\mathrm{TEA}^{+}\right)$was often added to the normal saline to reduce outward $\mathrm{K}^{+}$current.

Met-enkephalin and other peptides (Sigma) were pressure ejected from blunt-tipped puffer electrodes as described previously (Bixby and Spitzer, 1982). These electrodes contained the peptides in the same saline as that bathing the preparation, and pressures of 1 to 15 p.s.i. were used with tip sizes ranging from 3 to $9 \mu \mathrm{m}$. In some experiments naloxone was present in the perfusion solution.

\section{Results}

We initially tested Rohon-Beard neurons for a response to met-enkephalin at stage 26 (1 day after fertilization), the time at which they become sensitive to GABA and glycine. No change in resting membrane voltage or conductance was observed when concentrations of enkephalin up to $30 \mu \mathrm{m}$ were applied to the cells. However, the action potentials of these neurons, which depend on an influx of $\mathrm{Na}^{+}$and $\mathrm{Ca}^{++}$, were consistently shortened with enkephalin concentrations greater than or equal to $5 \mu \mathrm{M}$; the duration and amplitude of the $\mathrm{Ca}^{++}$. dependent component was reduced (Fig. 1A; Table I). The extent of this reduction varied from cell to cell; Figure $1 A$ illustrates one of the larger effects. Enkephalin can shorten the action potential at this stage in concentrations as low as $1 \mu \mathrm{M}$ (five of eight cells), but not at 0.1 $\mu \mathrm{M}$ (zero of four cells).

The action potentials remained shortened for the entire period of enkephalin application (up to $1 \mathrm{~min}$ ), with no apparent desensitization; durations returned to nor-

tial at stage 23. During enkephalin application (center traces), constant hyperpolarizing current pulses yield 20 to $30 \%$ larger voltage changes at comparable times after action potential initiation (arrowheads), indicating a decrease in conductance. The action potential amplitude, duration, and conductance return to normal when the enkephalin puff is turned off (righthand traces). $D, 1 \mu \mathrm{M}$ enkephalin shortens the $\mathrm{Ca}^{++}$plateau of the $\mathrm{Na}^{+} / \mathrm{Ca}^{++}$action potential elicited in the presence of $\mathrm{TEA}^{+}$ at stage 46 . The effect disappears when the puffer is turned off. $E, 20 \mu \mathrm{M}$ enkephalin has no apparent effect on the $\mathrm{Na}^{+}$action potential at stage 46 . 
TABLE I

Stage dependence of enkephalin ${ }^{a}$ effect on Rohon-Beard neurons

\begin{tabular}{cccc}
\hline Stage & $\begin{array}{c}\text { Action } \\
\text { Potential } \\
\text { Shortened }\end{array}$ & $\begin{array}{c}\text { Action } \\
\text { Potential } \\
\text { Lengthened }\end{array}$ & No Effect \\
\hline
\end{tabular}

no. of cells

\begin{tabular}{lrll}
20 & 2 & & \\
$21 / 22$ & 8 & $3^{b}$ & 1 \\
$23 / 24$ & 6 & & 1 \\
26 & 14 & - & 1 \\
$41 / 42$ & 2 & 3 & 3 \\
$45 / 46$ & 20 & 52 & \\
Total & & & \\
\hline
\end{tabular}

${ }^{a}$ Enkephalin concentration $\geq 5 \mu \mathrm{M}$.

${ }^{b}$ All of these cells were in one preparation.
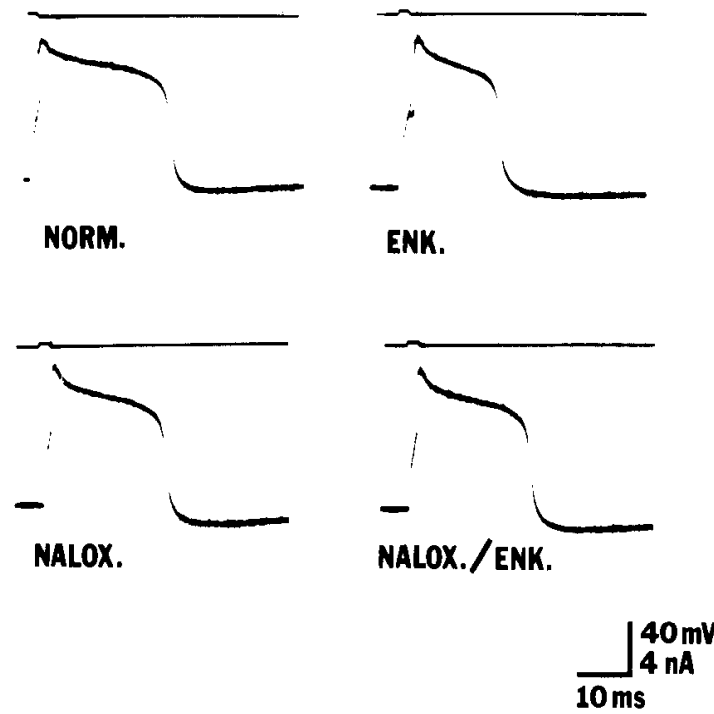

Figure 2. Five micromolar enkephalin shortens the $\mathrm{Ca}^{++}$ component of the action potential elicited in the presence of $\mathrm{TEA}^{+}$at stage 41 (upper traces). One micromolar naloxone prevents this effect (lower traces).

mal upon cessation of application. The latencies from onset of application to onset of full effect, and from end of application to the return of normal action potential duration, varied from undetectable to several seconds, but they seemed to be concentration dependent. The shortening of action potentials by enkephalin was a specific effect at all stages observed, in the sense that it was always abolished by low concentrations ( 1 to $10 \mu \mathrm{M}$ ) of naloxone ( $n=8$; Fig. 2 ).

Of the 18 cells tested at stage 26 , three exhibited an abnormal response, in which the action potential was longer in the presence of $10 \mu \mathrm{M}$ enkephalin. These cells were all from the same animal, in which other cells gave the usual response, and such an effect was never seen in any of the cells examined at other stages $(n=34)$. We have no explanation for this result.

Rohon-Beard neurons become capable of generating impulses around stage 20 , and we tested enkephalin on the $\mathrm{Ca}^{++}$action potentials of these early differentiating cells. Enkephalin (5 to $10 \mu \mathrm{M}$ ) markedly reduces the duration and peak amplitude of the early spike (Fig. $1 B$; Table I), and in some cases can prevent the generation of the impulse. Thus the response of the action potential to enkephalin is present in these neurons as soon as the $\mathrm{Ca}^{++}$channels become detectable by our techniques. The opiate reduces the conductance increase at the peak of these impulses (Fig. $1 C ; n=3$ ), suggesting that it acts by decreasing the inward current.

Although the $\mathrm{Ca}^{++}$component of the Rohon-Beard cell action potential is gradually reduced during the first week or so of development, $\mathrm{Ca}^{++}$channels can be revealed at stage 46 (the time onset of cell death; Lamborghini, 1981). The cells now generate predominantly $\mathrm{Na}^{+}$-dependent impulses in normal saline, but addition of $\mathrm{TEA}^{+}$decreases delayed rectification, and the $\mathrm{Ca}^{++}$ component is revealed as a plateau on the action potential (see Baccaglini and Spitzer, 1977). We took advantage of this procedure to determine whether $\mathrm{Ca}^{++}$currents of mature Rohon-Beard cells can be reduced by enkephalin. The characteristic $\mathrm{Ca}^{++}$-dependent plateau present in $\mathrm{TEA}^{+}$could be reliably shortened by enkephalin (1 to 10 $\mu \mathrm{M}$; Fig. $1 D$ ). Enkephalin was effective in concentrations as low as $0.1 \mu \mathrm{M}$ (two of five cells tested), a concentration ineffective on younger neurons. The explanation for the lower effective concentration with stage 46 neurons could be a lower density of $\mathrm{Ca}^{++}$channels.

The action of met-enkephalin on Rohon-Beard neurons seems to be limited to the effect on $\mathrm{Ca}^{++}$-dependent spikes. No change in the height or duration of stage 46 $\mathrm{Na}^{+}$-dependent action potentials was seen when enkephalin $(20 \mu \mathrm{M})$ was applied for 10 to $30 \mathrm{sec}(n=7$; Fig. $1 E)$. Enkephalin was also without consistent effect on the iontophoretic response to GABA in stage 46 cells $(n=5)$ and on the voltage-dependent uncoupling present in the embryonic neurons at earlier stages $(n=4)$ (see Bixby and Spitzer, 1982; Spitzer, 1982).

Other opiate peptides besides met-enkephalin can reduce the impulse duration of Rohon-Beard cells. Leuenkephalin is nearly as potent as met-enkephalin, working consistently at $10 \mu \mathrm{M}$ and sometimes at $2 \mu \mathrm{M}$ (two of four cells). Dynorphin and $\beta$-endorphin are also effective at $10 \mu \mathrm{M}$, but $1 \mu \mathrm{M}$ dynorphin elicited a barely detectable shortening, and $1 \mu \mathrm{M} \beta$-endorphin was ineffective $(n=$ 4). In contrast, oxytocin and substance $P$, two nonopiate neuroactive peptides, did not influence the height or duration of Rohon-Beard cell $\mathrm{Ca}^{++}$spikes at a concentration of $10 \mu \mathrm{M}(n=3$, substance $\mathrm{P} ; n=7$, oxytocin).

No effect on Rohon-Beard cell spike duration (stage 26) was observed when norepinephrine $(n=7)$, dopamine $(n=5)$, or 5 -hydroxytryptamine $(n=3)$ were perfused in the bathing saline at a concentration of $100 \mu \mathrm{M}$. In cultured chick dorsal root ganglion neurons (where enkephalin reduces the $\mathrm{Ca}^{++}$component of the spike), as well as in rat sympathetic cells, norepinephrine reduces the duration of $\mathrm{Ca}^{++}$-dependent impulses (Dunlap and Fischbach, 1978; Horn and McAfee, 1980).

Xenopus dorsal root ganglion neurons also exhibit action potentials with $\mathrm{Ca}^{++}$components (Baccaglini, 1978). We found that $20 \mu \mathrm{M}$ met-enkephalin reversibly shortened the duration of dorsal root ganglion neuron action potentials in vivo (Fig. 3$)(n=3)$.

\section{Discussion}

The shortening of $\mathrm{Ca}^{++}$-dependent action potentials reported here for spinal neurons in vivo is like that seen 


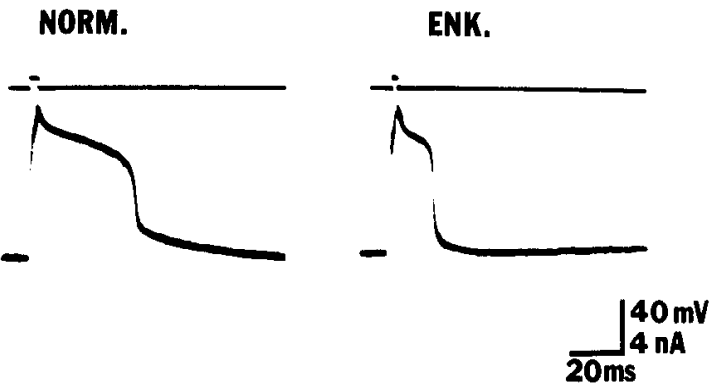

Figure 3. Twenty micromolar enkephalin reduces the $\mathrm{Ca}^{++}$ component of the action potential of a dorsal root ganglion neuron in $\mathrm{TEA}^{+}$saline at stage 49 .

in cultured chick dorsal root ganglion neurons, where the effect has been shown to be on $\mathrm{Ca}^{++}$channels (Fischbach et al., 1981). We believe that enkephalin is reducing $\mathrm{Ca}^{++}$ current in the Rohon-Beard neurons as well, rather than increasing $\mathrm{K}^{+}$current (Williams et al., 1982), for the following reasons. First, there is no effect on the height or duration of the $\mathrm{Na}^{+}$action potential present in the older neurons. Second, the shortening is seen in high concentrations of $\mathrm{TEA}^{+}$, which suggests that voltagesensitive $\mathrm{K}^{+}$channels are unlikely to be involved. Third, the principally $\mathrm{Ca}^{++}$-dependent action potential of the embryonic neurons can be appreciably reduced in height or even blocked by enkephalin, lessening the possibility of the effect being mediated through $\mathrm{K}^{+}$channels which open with some delay upon depolarization (see, however, MacDermott and Weight, 1982). Finally, direct measurements of the membrane conductance during these action potentials suggest that it is decreased by enkephalin.

The opiate peptides have been shown to be involved in a diverse set of physiological effects, including changes in resting membrane potential and conductance, and in the postsynaptic response to neurotransmitters (e.g., Barker et al., 1978). A consistent finding has been, though, that opiates reduce or block responses involving voltagesensitive $\mathrm{Ca}^{++}$channels, an effect seen both in vitro and in several systems in vivo, including the present result in Xenopus dorsal root ganglion neurons. It seems that the action of enkephalin on Rohon-Beard cells is restricted to this latter category.

There are various possible explanations for the observed variability in the magnitude of the enkephalin effect. There may be biological variation in the number or types of receptors. Alternatively, difficulties in delivering known concentrations to the cell surface could have arisen, due to differences in diffusion barriers or in puffer characteristics.

The Rohon-Beard cell response to enkephalin is present at least as early as stage 20, approximately $21 \mathrm{hr}$ after fertilization. It is, therefore, among the earliest signs of physiological differentiation detected in these embryonic neurons to date. By contrast, the other known chemosensitivities of the cells, to GABA and glycine, appear first around stage 25 (Bixby and Spitzer, 1982). We have commented before on the apparent tendency for the simultaneous appearance of sensitivity to different neurotransmitters, which has been seen for GABA and glycine in Rohon-Beard neurons and for GABA and acetylcholine in the dorsal unpaired median neurons of the grasshopper (Goodman and Spitzer, 1979; Bixby and Spitzer, 1982). The early appearance of enkephalin sensitivity in Rohon-Beard neurons is an exception to this tendency. However, it may be that the binding site for enkephalin in Rohon-Beard neurons is a transmitter receptor only in the most general sense. That is, our results would be explained if enkephalin exerted its action by binding directly to the voltage-dependent $\mathrm{Ca}^{++}$channel. If enkephalin had the ability to block $\mathrm{Ca}^{++}$channels in this way, one might expect that it would do so in a wide variety of neurons, as seems to be the case. We have recently shown, for example, that enkephalin reduces quantal content at the frog neuromuscular junction, apparently by blocking $\mathrm{Ca}^{++}$influx (Bixby and Spitzer, 1983). It should be noted, however, that we have no direct evidence supporting this mechanism of action of enkephalin.

The physiological role of the Rohon-Beard cell sensitivity to enkephalin is unknown. Preliminary immunocytochemical results suggest that enkephalin is present in the dorsal spinal cord during development (J. E. Lamborghini and H. J. Karten, personal communication). It is possible, as has been suggested for other neural systems, that the reduction in $\mathrm{Ca}^{++}$current is related to the regulation of neurotransmitter release, presumably involving $\mathrm{Ca}^{++}$channels at the axonal terminals. However, it may also be that the function of enkephalin is in modulating the somatic $\mathrm{Ca}^{++}$action potentials which are transiently expressed in Rohon-Beard cells. It is unlikely that the shift in ionic dependence of the inward current of the action potential is the result of suppression of the $\mathrm{Ca}^{++}$component by endogenous opiate peptides, because it also occurs in neurons in dissociated cell culture (Spitzer and Lamborghini, 1976). The physiological significance of these long duration $\mathrm{Ca}^{++}$action potentials is still obscure.

\section{References}

Akaike, N., K. S. Lee, and A. M. Brown (1978) The calcium current of Helix neuron. J. Gen. Physiol. 71: 509-531.

Baccaglini, P. I. (1978) Action potentials of embryonic dorsal root ganglion neurones in Xenopus tadpoles. J. Physiol. (Lond.) 283: 585-604.

Baccaglini, P. I., and N. C. Spitzer (1977) Developmental changes in the inward current of the action potential of Rohon-Beard neurones. J. Physiol. (Lond.) 271: 93-117.

Barker, J. L., T. G. Smith, and J. H. Neale (1978) Multiple membrane actions of enkephalin revealed using cultured spinal neurons. Brain Res. 154: 153-158.

Bixby, J. L., and N. C. Spitzer (1982) The appearance and development of chemosensitivity in Rohon-Beard neurones of the Xenopus spinal cord. J. Physiol. (Lond.) 330: 513-536.

Bixby, J. L., and N. C. Spitzer (1983) Enkephalin reduces quantal content at the frog neuromuscular junction. Nature 301: 431-432.

Dunlap, K., and G. D. Fischbach (1978) Neurotransmitters decrease the calcium component of sensory neuron action potentials. Nature 276: 837-839.

Fischbach, G. D., K. Dunlap, A. Mudge, and S. Leeman (1981) Peptide and amine transmitter effect on embryonic chick sensory neurons in vitro. In Neurosecretion and Brain Peptides, J. B. Martin, S. Reichlin, and K. L. Bick, eds., pp. 175-188, Raven Press, New York.

Goodman, C. S., and N. C. Spitzer (1979) Embryonic development of identified neurones: Differentiation from neuroblast 
to neurone. Nature 280: 208-214.

Horn, J. P., and D. A. McAfee (1980) Alpha-adrenergic inhibition of calcium-dependent potentials in rat sympathetic neurons. J. Physiol. (Lond.) 301: 191-204.

Jessell, T. M., and L. L. Iversen (1977) Opiate analgesics inhibit substance $\mathrm{P}$ release from rat trigeminal nucleus. Nature 268: 549-551.

Kano, M. (1975) Development of excitability in embryonic chick skeletal muscle cells. J. Cell. Physiol. 86: 503-510.

Koketsu, K., and S. Nishi (1969) Calcium and action potentials of bullfrog sympathetic ganglion cells. J. Gen. Physiol. 53: 608-623.

Konishi, S., A. 'Isunoo, and M. Otsuka (1979) Enkephalins presynaptically inhibit cholinergic transmission in sympathetic ganglia. Nature 282: 515-516.

Lamborghini, J. E. (1981) Kinetics of Rohon-Beard neurone disappearance in Xenopus laevis. Soc. Neurosci. Abstr. 7: 291.

Lightman, S. L., L. L. Iversen, and M. L. Forsling (1982) Dopamine and [D-Ala ${ }^{2}, \mathrm{n}-\mathrm{Leu}^{5}$ ]enkephalin inhibit the electrically stimulated neurohypophyseal release of vasopression in vitro: Evidence for calcium-dependent opiate action. J. Neurosci. 2: 78-81.

MacDermott, A. B., and Weight, F. F. (1982) Action potential repolarization may involve a transient, $\mathrm{Ca}^{++}$-sensitive outward current in a vertebrate neuron. Nature 300: 185-188.

MacDonald, R. L., and P. G. Nelson (1978) Specific opiate- induced depression of transmitter release from dorsal root ganglion cells in culture. Science 199: 1449-1457.

Mudge, A. W., S. E. Leeman, and G. D. Fischbach (1979) Enkephalin inhibits release of substance P from sensory neurons in culture and decreases action potential duration. Proc. Natl. Acad. Sci. U. S. A. 76: 526-530.

Nieuwkoop, P. D., and J. Faber (1956) Normal Table of Xenopus laevis (Daudin), North Holland Press, Amsterdam.

Spitzer, N. C. (1982) Voltage and stage dependent uncoupling of Rohon-Beard neurones during embryonic development of Xenopus tadpoles. J. Physiol. (Lond.) 330: 513-536.

Spitzer, N. C., and J. E. Lamborghini (1976) The development of the action potential mechanism of amphibian neurons isolated in culture. Proc. Natl. Acad. Sci. U. S. A. 73: 16411645.

Strichartz, G., R. Small, C. Nicholson, K. H. Pfenninger, and R. Llinas (1980) Ionic mechanisms for impulse propagation in growing nonmyelinated axons: Saxitoxin binding and electrophysiology. Soc. Neurosci. Abstr. 6: 660.

Williams, J. T., T. M. Egan, and R. A. North (1982) Enkephalin opens potassium channels on mammalian central neurons. Nature 299: 74-77.

Yoshida, S., Y. Matsuda, and A. Samejima (1978) Tetrodotoxinresistant sodium and calcium components of action potentials in dorsal root ganglion cells of the adult mouse. J. Neurophysiol. 41: 1096-1106. 